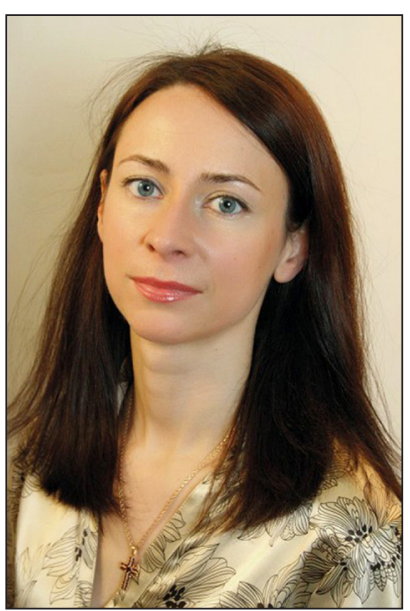

Semyonkina Irina,

Associate Professor, candidate of Psychological Sciences Foreign Languages Department №1, Yaroslav Mudryi National Law University, Yaroslav Mudryi National Law University, Ukraine, Kharkov, e-mail: isemyonkina@mail.ru ORCID 0000-0002-7181-5923;

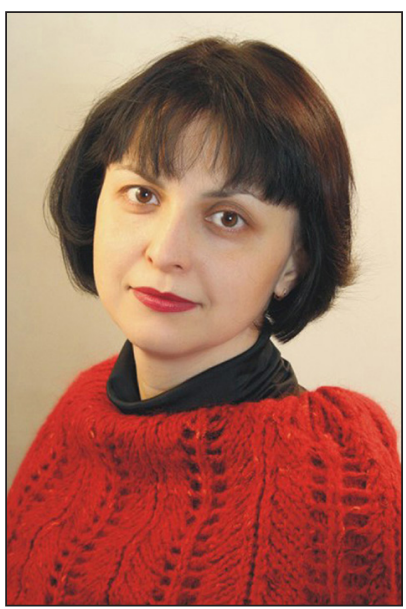

Khodakovska Oksana, Associate Professor, candidate of Philological Sciences Foreign Languages Department №1, Ukraine, Kharkov, e-mail: http-ok@yandex.ru ORCID 0000-0002-2168-4558

\title{
UDC 378:34:811.111
}

\section{WHAT DOES THE FUTURE HOLD FOR LEGALESE}

Specific features of the English legal discourse and trends of its transformationin the context of global challenges have been considered in the paper.

Key words: legalese; plain English; legal discourse; legal writing; law.

Семёнкина И. А., кандидат психологических наук, доцент, доцент кафедры иностранных языков № 1, Национальный юридический университет имени Ярослава Мудрого, Украина, г. Харьков.

e-mail: isemyonkina@mail.ru ; ORCID 0000-0002-7181-5923

Ходаковская О. A., кандидат филологических наук, доцент, доцент кафедры иностранных языков № 1, Национальный юридический университет имени Ярослава Мудрого, Украина, г. Харьков.

e-mail: http-ok@yandex.ru ; ORCID 0000-0002-2168-4558

Что ожидает в будущем юридический английский язык

В статье анализируются специфические черты англоязычного юридического дискурса и тенденции его трансформации в контексте глобальных вызовов. 
Ключевые слова: юридический английский язык; простой английский язык; английский юридический дискурс; юридические документы; право.

The minute you read something that you can't understand, you can almost be sure that it was drawn up by a lawyer.

Will Rogers

Problem setting. For over nine hundred years, users of English, French and Latin have competed with one another for dominance of the legal language.

Following the Norman invasion almost all writing was done in French or Latin. As late as in 1356, the Statute of Pleading (ironically written in French) was enacted, stating that all legal proceedings should be in English, but recorded in Latin. English was adopted for different kinds of legal documents at different times. Wills began to be written in English in about 1400. Statutes were written in Latin until about 1300, in French until 1485, in English and French for a few years, and in English alone from 1489. However French was used in legal pleadings in some areas of the law well into the seventeenth century. This is when new branches of law, such as commercial law took their position and consequently developed entirely in English, relatively free of French influence.

As the printed word became the part of everyday life and a greater proportion of population was able to read, many writers of legal documents deliberately introduced words derived from Latin (and even Latin word order) - in an attempt to make their work more sophisticated and meaningful. On account of that, the style of legal writing has become excessively ornate - with an idea to impress rather than to inform.

Recent research and publications analysis. Legal discourse, according to Otto Walter, can be divided into four categories according to the functional areas of law, namely: -1 ) language of laws (legal texts intended by the legislator for both specialists and non-specialists (laws, etc.)); 2) the language of legal science and expertise (professional comments and discussion questions that occur within professional communication); 3) written language of departmental communication (forms, summons, etc.); 4) administrative jargon (informal discussion of specific issues experts) [7, p. 44-57].

The integral feature of legal discourse is the situation of communication in the legal sphere, which together with extralinguistic factors determines its specific linguistic characteristics. The main component of the legal discourse is the text of the legal document which eventually is the impetus for social and legal development of any society.

At times legalese appears to be perplexing and almost willfully perverse. Standard legal agreements, for example, typically contain some version of the following clause: «The masculine shall include the feminine, the singular shall include the plural, and the present tense shall include the past and future tense». Or consider these classic legalese words of Judge Kaplan in Board of Health of North Adams v Mayor of North Adams: «In resolving the question whether, and how, to count ballots not marked by voters in accordance with instructions, so that the intent of the 
voter is unclear, we have said that if the intent of the voter can be determined with reasonable certainty from an inspection of the ballot, in the light of the generally known conditions attendant upon the election, effect must be given to that intent and the vote counted in accordance therewith» [2].

Another factor explaining the use of complicated legal language is the desire to hide the truth, confuse the audience and complicate the understanding of information: «It [legalese] dissects the way in which the US government legalised torture in its prisons in Iraq and Guantanamo by continually redefining their interrogation practices and surrounding them in a fog of legalese» [8].

Paper objective. Often used as a pejorative term for written forms of legal English, dense and pedantic legalese is an integral part of legal culture. In this paper we attempt to examine the changing nature of legal English, which despite its conservatism and traditionalism is undergoing gradual transformations under the pressure of modern realia, including global social economic challenges and scientific and technological advance.

Paper main body. As the law evolved, the language evolved, incorporating legal expressions in all three languages, all in active use.

As Mellinkoff stated: «legalese is a way of preserving a professional monopoly by locking the trade secrets in the safe of unknown tongue» [5, p. 45]. Legalese as a term has a number of interpretations, the following definition is considered to be the most successful: «This is a special legal language, a special way of construction of phrases and sentences, which for those unfamiliar with the intricacies of English legal terminology often seems devoid of content».

Specific characteristics of legalese include: extensive use of words and phrases derived from French and Latin (ex post facto, voir dire); doublets and triplets (cease and desist; in my name, place, and stead); alliteration (lewd and lascivious; rest, residue, and remainder); using pairs of words with a reciprocal relationship (lessor/lessee); use of terms of art (fictitious defendant, garnishment, injunction); use of Old English and Middle English words (hereafter, herein, hereof, hereto); unusual word order (will at the cost of the borrower forthwith comply with the same); argot (prescriptive right, four corners of the instrument, clean hands). There is also a small group of words that have one meaning as a legal term of art and another meaning in ordinary English.

\begin{tabular}{|l|l|}
\hline \multicolumn{1}{|c|}{ Word and its legal English meaning } & Word and its ordinary English meaning \\
\hline $\begin{array}{l}\text { Consideration - act, forbearance, or } \\
\text { promise by one party to a contract }\end{array}$ & $\begin{array}{l}\text { Consideration - (1) careful thought, } \\
\text { (2) a fact taken into account when } \\
\text { that constitutes the price for which the } \\
\text { making a decision, } \\
\text { promise of the other party is bought. } \\
\begin{array}{l}\text { Consideration is essential to the } \\
\text { validity of any contract other than one } \\
\text { made by deed }\end{array}\end{array}$ \\
\hline
\end{tabular}




\begin{tabular}{|l|l|}
\hline $\begin{array}{l}\text { Construction - interpretation. 'To } \\
\text { construe' is the } \\
\text { infinitive verb form of the term. }\end{array}$ & $\begin{array}{l}\text { Construction - (1) the action of } \\
\text { constructing [e.g. a building]; } \\
\text { (2) a building or other structure; } \\
\text { (3) the industry of erecting buildings. }\end{array}$ \\
\hline $\begin{array}{l}\text { Prayer - form of pleading request } \\
\text { addressed to the court }\end{array}$ & $\begin{array}{l}\text { Prayer - a solemn request for help or } \\
\text { expression of thanks addressed to God } \\
\text { or another deity }\end{array}$ \\
\hline
\end{tabular}

Among other pitfalls of Legalese we should mention semantic and syntactic ambiguity, avoiding personal pronouns, high abstraction, general and vague terms, solemnity of form, inflated verbiage, the specific use of the modal verb «shall», over-specificity and too many choices etc. Besides, Legalese is characterized by almost complete absence of punctuation (except the point). Peter Butt gives an example of the legal text, which, according to his calculations, contains 763 words and only two commas and one semicolon: «Also interest upon all such moneys as aforesaid or on so much thereof as shall for the time being be owing or payable or remain unpaid without (unless the Bank otherwise in writing agrees) allowing credit for any credit balance in any account or accounts of the Mortgagor and the Debtor or either of them either alone or jointly with any other person with the Bank at the rate or respective rates agreed upon in writing if any and in the absence of any such agreement then without prior or other notice to the Mortgagor or to the Debtor at such rate or rates as the Bank from time to time determines: except as otherwise provided by the terms of any agreement in writing relating to the whole or part of such moneys such interest shall accrue from day to day and shall be computed from the day or respective days of such moneys being paid or disbursed or becoming owing and at the end of every period of such duration as the Bank may from time to time determine and ending at the end of such day as the Bank may from time to time determine [...] that the amount of moneys deemed to have remained unpaid shall not include such sums as the Bank shall have received in respect thereof». He also drews attention to another quite revealing passage that is extremely complex and almost devoid of punctuation: «[The tenant shall] when where and so often as occasion requires well and sufficiently ... repair renew rebuild uphold support sustain maintain pave purge scour cleanse glaze empty amend and keep the premises and every part thereof... and all floors walls columns roofs canopies lifts and escalators ... shafts stairways fences pavements forecourts drains sewers ducts flues conduits wires cables gutters soil and other pipes tanks cisterns pumps and other water and sanitary apparatus thereon with all needful and necessary amendments whatsoever ...» [4].

Despite claims «Complex concepts require complex language», a significant number of documents is written in simple language. But there is a discussion whether a plain language should be considered safe for use in legal discourse. On many occasions, the preference is still given to legalese. The reason is that it is very difficult to find similar terms using ordinary language only. Also scientists 
ignore the fact that judges prefer the traditional use of law language thus while rendering a verdict, they use the complex legal language, although not all legal documents and laws should be written considering legalese.

As far back as in 1944 a US Congressman named Maury Maverick wrote a memo, banning all «gobbledygook language» from his office, referring to confusing or a generally unintelligible use of jargon common for legalese, officialese or bureaucratese. Being quite outspoken he added in his memo, «Anyone using the words 'activation' or 'implementation' will be shot».

Since 1970 various campaigns in the USA and UK promoted the use of «Plain English» in all spheres (particular areas of focus are official documents and publications, and the language of Law). Plain English refers to: «the writing and setting out of essential information in a way that gives a co-operative, motivated person a good chance of understanding the document at first reading, and in the same sense that the writer meant it to be understood» [1].

A number of states in the USA have acknowledged the limitations of legalese jury instructions. First among them is California, which officially replaced its legalese jury instructions with plain English jury instructions for civil cases in 2003, for example [3]:

\begin{tabular}{|l|l|}
\hline \multicolumn{1}{|c|}{ Before } & \multicolumn{1}{c|}{ After } \\
\hline Proof beyond a reasonable doubt & $\begin{array}{l}\text { Proof that leaves you with an abiding } \\
\text { conviction that the charge is true }\end{array}$ \\
\hline A preponderance of the evidence & More likely than not \\
\hline $\begin{array}{l}\text { Failure of recollection is common Innocent } \\
\text { misrecollection is not uncommon }\end{array}$ & $\begin{array}{l}\text { People often forget things or make } \\
\text { mistakes in what they remember }\end{array}$ \\
\hline
\end{tabular}

New Zealand established a number of The Plain English Awards in 2006. Every year, any organisations or ordinary citizens are allowed to submit documents and websites that are great examples of plain English - or of gobbledygook.

The Awards aim at:

- improving government and business documents so that all New Zealanders can understand them

- raising public awareness of the need for, and benefits of, plain English creating a public preference for organisations that choose to communicate in plain English [9].

Resulted from the facts, a special independent board of plain English experts and advocates study the documents and choose the finalists and winners in the following categories: Plain English Champion, Best Organisation, Best Individual or Team, Best Project, Best Plain English Document, Best Plain English Website, Best Plain English Sentence Transformation, Best Plain English Annual Report, 
Best Plain English Legal Document, Best Plain English Technical Communicator, Best Plain English Turnaround, and People's Choice in Best Plain English Communication or Worst «Brainstrain» Communication.

More recently in 2008, the Chairman of the U.S. Securities \& Exchange Commission, Christopher Cox, spoke before the Subcommittee on Contracting and Technology, of the Committee on Small Business, of the U.S. House of Representatives, on the topic «Plain Language - The Benefits to Small Business». The main message of the report can be presented as the following: «At the SEC, we have more modest penalties in store for both staff and public offenders. But we're dead serious about plain English. That's because it's our job to be the investor's advocate, and investors deserve concise and clearly written disclosure that helps them quickly focus on what's important in making financial decisions. Using plain English respects the fact that investors are busy people, and lets them use their time more productively. Clearly presented information also makes investment analysts and every other market actor more efficient. It improves the process of price discovery on our securities exchanges. And by exposing the financial doings of public companies to more direct sunlight, it makes our markets more honest - strengthening investor confidence.»

In the UK Plain English Campaign Movement has established Plain English Day that is celebrated on December, 1. The Organisation praises both good and bad examples of language usage in all spheres of life. Some of the awards appear to be rather sarcastic: i.e. this year, Donald Trump wins a Foot in Mouth Award.

Although the movement to draft legal texts in standard, modern English is in progress and experts are busy trying to demystify legalese, this process is quite slow.

Having arisen from a need for precision (even overparticularity), legalese may be more precise in comparison with plain English. Legal writing implies an endeavor to cover all possible contingencies while remaining reasonably brief. Besides, the long history of use of legalese provides a similarly extensive background of precedent tied to the language. This precedent will be a strong determinant of how documents written in legalese will be interpreted.

Remarkably legal writing has not escaped the domination and magnetism of the IT world. Tablets, smart phones, the Internet, social media are all results of revolutionary innovations, which have dramatically changed our lives. And they all have come from an attempt to explore an unknown or innovative business model in order to disrupt existing markets - from startups.

According to Dr. Paul D. Reynolds, Director of Research Institute of the Global Entrepreneurship Center, world wide, there are about 300 million persons trying to start about 150 million businesses. About one third will be launched, so about 50 million new firms are born per year.

Under the pressure of time, startups and venture capitalists (VCs) are beginning to need a better and quicker way to get past the legal fundamentals. Starting a company requires a number of legal documents, and raising money will require even more. Incorporation documents, term sheets, vesting clauses, milestones and deliverables - all these need to be spelt out clearly and appropriately. The normal 
response in this situation is to hire a lawyer. But startups aren't normal. They don't want to spend any money on lawyers. Is there a better way? The startups offering legal services have their own solution, where law meets computer science: «Software is eating law». The software they are offering produces complete, consistent, coordinated sets of documents that confidently move your company's state vector from A to B. According to the developers: «...Legalese is the open source member of that family, created by hackers, for hackers, to help founders and investors configure and compile the «loadable modules» for startups: ESOPs, vesting schedules, convertible notes, and equity angel rounds are just another problem in algorithms and data structures.» The prevailing response with investors has been enthusiastic, fuelling greater interest in automating the process of drafting legal documents. There are however legal challenges faced by the developers. From the legal standpoint, due to the obscure language and jargon in legislation, it is not exactly clear if this is entirely legal. An open source advocate, Wong believes that people should be able to conduct their own legal agreements without having to pay lawyer fees. «They should be able to get decent software to do the intelligence.» While the legality of charging for drafting legal documents remains ambiguous, Legalese.io will be free for users to create and draft documents such as term sheets.

Conclusions of the research. Overall, currently the Plain English campaign covers all spheres of life. Having started as a movement for clear and simple legal writing, it has gained support in all parts of the world and covered nearly all areas of law, business, government and IT technologies. The campaigners of plain English volunteer to implement it in government, commercial, legal, and even in leisure activities, moreover, it can save costs significantly. The latter eventually allows business to work more effectively.

In the context of globalization, to a great extent conditioned by disruptive technologies, when English as a second language is spoken by more people than native speakers, the need for plain English implies intense pressure on the norms of Legal English - forcing it ultimately to transform and evolve.

Further studies regarding the long-term prospects of legalese would be interesting for both lawyers and linguists.

\section{Список літератури:}

1. Полубиченко Л. В. Язык юридической документации как объект учебного перевода в функционально-стилистическом аспекте / Л. В. Полубиченко, Н. П. Глинская // Вестник МГУ. Сер. 19. Лингвистика и межкультурная коммуникация. - 1999. - № 3. - С. 116-128.

2. Томсон Г. В. Курс юридического перевода (гражданское и торговое право) / Г. В. Томсон. - Москва : МГИМО, 2004.

3. Bast C. Lawyers Should Use Plain Language / C. Bast // Florida Bar Journal. - 1995. № 10. - P. 3-10.

4. Butt P. Legalese versus Plain Language / P. Butt // Amicus Curiae Issue. - № 35. - 2001. P. $28-32$.

5. Mellinkoff D. The Language of the Law / D. Mellinkoff. - Boston : Little, Brown and Co, 1963. $-526 \mathrm{p}$. 

1935.

6. Rogers Will. The Lawyers Talking / Will Rogers // Weekly Article. - Issue 657. - July 28,

7. Otto W. Die Paradoxie einer Fachsprache / Walter Otto. - Stutgart : Der offentliche Sprachgebrauch. Band II, 1981. - 678 s. legalese.

8. Taxi to the Dark Side. - Retrieved from : http://legal-dictionary.thefreedictionary.com/

9. What are the awards about. - Retrieved from : http://www.plainenglishawards.org.nz/whatare-the-awards-about/

\section{References:}

1. Polubichenko, L. V., Glinskaja, N. P. Jazyk juridicheskoj dokumentacii kak ob’ekt uchebnogo perevoda $\mathrm{v}$ funkcional'no-stilisticheskom aspekte [The language of legal documents as an object of educational translation in the functional-stylistic aspect] Vestnik MGU. Ser.19. Lingvistika i mezhkul'turnaja kommunikacija. [in Russian]

2. Tomson, G.V. Kurs juridicheskogo perevoda (grazhdanskoe i torgovoe pravo) [The course of legal translation (civil and commercial law)] - Moscow: MGIMO, 2004. [in Russian].

3. Bast, C. Lawyers Should Use Plain Language. Florida Bar Journal. 1995. 10. pp. 3 - 10.

4. Butt P. Legalese versus Plain Language. Amicus Curiae Issue. 35. 2001. PP. 28 - 32.

5. Mellinkoff, D. The Language of the Law. - Boston: Little, Brown and Co, 1963. - 526 p.

6. Rogers, Will. The Lawyers Talking. Weekly Article. - Issue 657. - July 28, 1935.

7. Otto, W. Die Paradoxie einer Fachsprache. - Stutgart: Der offentliche Sprachgebrauch. Band II, 1981. $-678 \mathrm{~s}$.

8. Taxi to the Dark Side. - Retrieved from: http://legal-dictionary.thefreedictionary.com/legalese

9. What are the awards about. - Retrieved from: http://www.plainenglishawards.org.nz/whatare-the-awards-about/

Cемъонкіна I. A., кандидат психологічних наук, доцент, доцент кафедри іноземних мов № 1, Національний юридичний університет імені Ярослава Мудрого, Україна, м. Харків.

e-mail: isemyonkina@mail.ru ; ORCID 0000-0002-7181-5923;

Ходаковсъка О. О., кандидат філологічних наук, доцент, доцент кафедри іноземних мов № 1, Національний юридичний університет імені Ярослава Мудрого, Україна, м. Харків.

e-mail: http-ok@yandex.ru ; ORCID 0000-0002-2168-4558

Що чекає в майбутньому на юридичну англійську мову

У статті автори намагаються проаналізовати специфічні риси англомовного юридичного дискурсу та тенденції його трансформації у контексті глобальних викликів.

Джерелом юридичних текстів є професіонали-юристи, які створюють ці тексти, враховуючи особливості устрою суспільства. Статус права є надзвичайно високим та відповідальним, його мова $є$ показником рівня культури законодавців, їх поваги до громадян. Мова юридичних документів типово є ритуальною та архаїчною, вона підпорядковується дуже суворим стилістичним нормам у відношенні способу висловлювання і регістру, а також високою мірою кодифікованих жанрових структур. Стиль більшості документів не повинен викликати додаткових асоціацій та відвертати увагу від суті документа, відсутні будь-які індивідуально-авторські риси. Нейтральне викладення юридичних норм підвищує ефективність правового регулювання.

У контексті глобалізації необхідність трансформації англійської юридичної мови в площині більшої транспарентності об’єктивно обумовлена новими викликами сучасного світу.

Ключові слова: юридична англійська мова; проста англійська мова; англійський юридичний дискурс; юридичні документи; право. 